02

\title{
FT-IR-спектры многослойного графена и его композиции с поверхностно-активным веществом
}

\author{
(ㄱ И.Ю. Денисюк, К.Ю. Логушкова, М.И. Фокина, М.В. Успенская \\ Университет ИТМО, \\ 197101 Санкт-Петербург, Россия \\ e-mail: denisiuk@mail.ifmo.ru
}

Поступила в редакцию 17.10.2018 г.

\begin{abstract}
Многослойный графен получен методом ультразвукового расщепления микрочастиц графита в поверхностно-активном растворителе, смеси нонана и воды, выбран поверхностно-активный сурфактант, обеспечивающий диспергирование графена в гидрофильных системах. Методом ИК фурье-спектроскопии исследована химическая структура полученных материалов. Обсуждены возможные механизмы влияния неорганических ПАВ (натриевое жидкое стекло) на графен, тип связей, возникающих между ним и поверхностью графена, и возможные области его применения.
\end{abstract}

DOI: $10.21883 /$ OS.2019.02.47200.300-18

\section{Введение}

Графитовые наномодификаторы, такие как фуллерен, графитовые нанотрубки, монослойный графен, являются трендом современного материаловедения. Введение небольших, не более десятой или даже сотой доли процента, добавок углеродных наночастиц, имеющих развитую и активную поверхность, позволяет обеспечить новые свойства материалов, такие как сорбционная способность по отношению к тяжелым металлам [1], барьерные свойства, биоцидные свойства и многое другое. Основной недостаток традиционных углеродных наночастиц - их высокая стоимость, которая препятствует широкому их применению. По этой причине в последнее время повысился интерес к наноплоскостям графита, названным многослойным или техническим графеном, получение которого основано на расщеплении природного графита на отдельные плоскости, которое происходит обычно за счет окисления графита в среде сильных окислителей и последующего разрушения его ультразвуком по одной из реализаций метода Хаммера [2]. Недостатком метода является его сложность и необходимость применения метастабильных растворителей с выходом токсичных продуктов реакции, что ограничивает практическое применение. Поэтому в последнее время проводятся исследования процессов разрушения графита при совместном действии ультразвука и ПАВ, которое требует большей подводимой ультразвуковой мощности, но используемые вещества нетоксичны, а процесс пригоден для масштабирования до уровня производства технического продукта.

В настоящей работе проведено подобное исследование процесса расщепления графита на наноплоскости многослойного графена методом ультразвукового разрушения порошкообразного природного графита в присутствии поверхностно-активного растворителя в соответствии с общей схемой химической реакции, описание которой приведено в работе [3].

\section{Аппаратура и условия эксперимента}

Наномодифицированный графит был приготовлен путем ультразвукового расщепления порошкообразного графита марки C-1 (размер частиц 10-20 $\mu \mathrm{m}$ ) в нонане и затем в его смеси с водой. Диспергирование графита проводилось с использованием ультразвукового диспергатора УЗД2-0,063/22 (мощность ультразвука $60 \mathrm{~W}$ ) при плотности мощности $70 \mathrm{~W} / \mathrm{cm}^{2}$. Для повышения плотности мощности в области разрушения частиц графита, опадающих на дно, звукопровод диспергатора погружался в пробирку, в которой проводилось разрушение графита.

Порошкообразный графит в количестве $2 \mathrm{~g}$ был помещен в пробирку диаметром $25 \mathrm{~mm}$ с $20 \mathrm{ml}$ нонана (XЧ). Диспергирование на полной мощности $60 \mathrm{~W}$ проводилось в течение $30 \mathrm{~min}$, после этого добавлено $20 \mathrm{ml}$ дистиллированной воды, и диспергирование было продолжено в течение $5 \mathrm{~h}$. В процессе диспергирования образовалась эмульсия нонана в воде, в которой и проходил процесс разрушения графита. Пробирка охлаждалась проточной водой. После окончания процесса растворитель был слит декантацией, а осадок высушен в сушильном шкафу при $100^{\circ} \mathrm{C}$ в течение $2 \mathrm{~h}$.

Процесс расщепления основан на специфическом взаимодействии поверхности графита с алифатическими углеводородами, период молекулы которых равен периоду расположения атомов углерода в кристалле графита [4]. Процесс ультразвукового разрушения графита был описан ранее [3]. Нонан, имея одинаковый период атомов углерода в молекуле с периодом шестигранников графита в плоскости, адсорбируется на нем и может войти в виде одиночных молекул между плоскостями при инициировании процесса мощным ультразвуковым воздействием, вызывая отшелушивание отдельных наноплоскостей (рис. 1). 


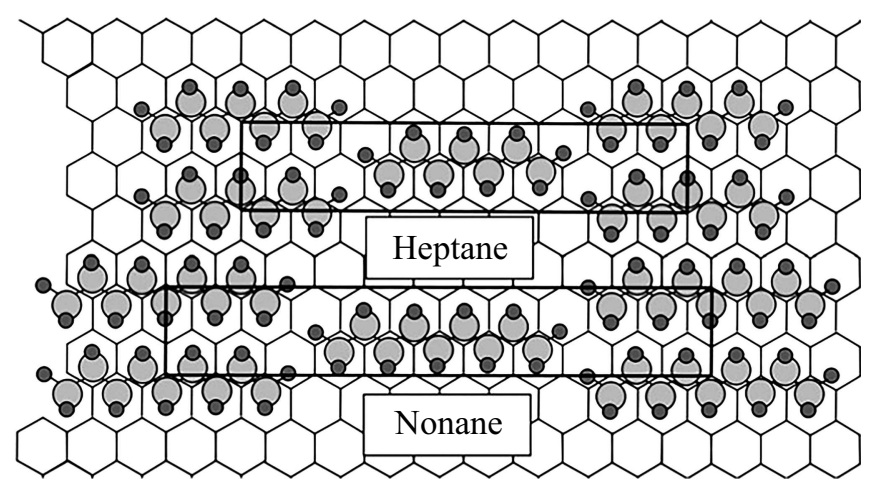

Рис. 1. Соотношение размеров решетки графита с периодом углерода алифатических растворителей [4].

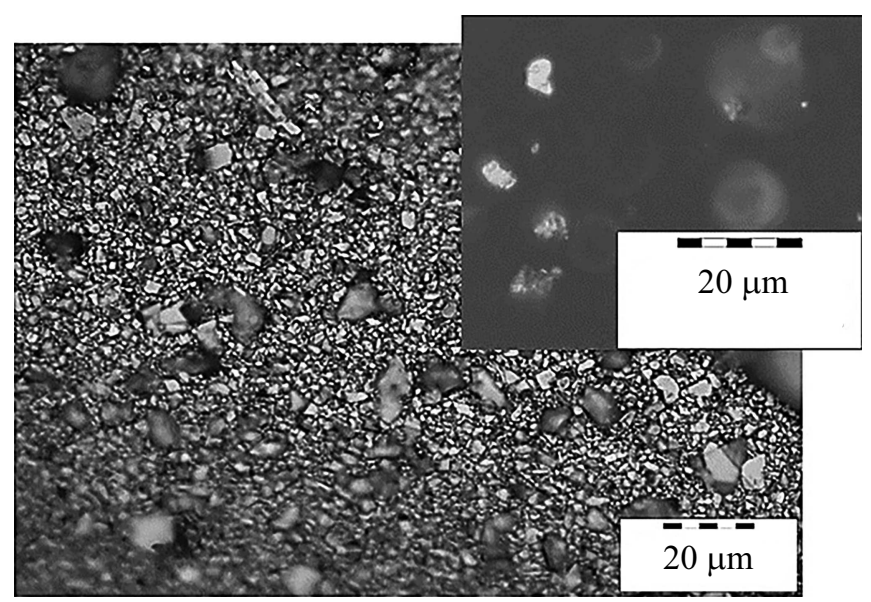

Рис. 2. Плоскости графена, полученные ультразвуковым разрушением микрочастиц графита. На врезке они же, диспергированные в жидком стекле.

Микроскопические исследования проводились на микроскопе Olympus STM 6 в отраженном свете с поляризационным и интерференционным контрастом.

Инфракрасный спектр пропускания в интервале $3200-450 \mathrm{~cm}^{-1}$ записан на ИК фурье-спектрофотометре ФСМ-1201 (ООО „Мониторинг“). Для измерения ИК спектров материал нагревался в муфельной печи с целью удаления воды, адсорбированной на поверхности. Как следует из результатов работы [5], окисление графита на воздухе начинается при $250-300^{\circ} \mathrm{C}$ и идет интенсивно при $400^{\circ} \mathrm{C}$, поэтому прокаливание графита для удаления влаги проводилось при пониженной температуре - не выше $200^{\circ} \mathrm{C}$.

Процесс смешивания жидкого стекла с предварительно приготовленным графеном проводился под действием ультразвука. Для этого навеска $0.5 \mathrm{~g}$ сухого графена была помещена в бюкс с $10 \mathrm{ml}$ жидкого стекла. Диспергирование проводилось в течение $1 \mathrm{~h}$ до образования черной однородной вязкой жидкости, которая затем могла быть введена в связующее.

\section{Результаты и их обсуждение}

Полученный графен представляет собой кристаллические микропластинки толщиной около 100-500 nm и латеральным размером $1.5 \mu \mathrm{m}$. Микрофотография полученного материала приведена на рис. 2. Внешне нанопластины графена представляют собой плотный осадок черного цвета, который после высыхания приобретает металлический блеск.

Спектры исходного графитового порошка и графена, полученного в данной работе, представлены на рис. 3.

Сравнение спектров показывает, что при ультразвуковом расшелушивании микрочастиц графита и получения наноплоскостей графена появляются два максимума поглощения при 1273 и $2373 \mathrm{~cm}^{-1}$, которые мы отнесли к связям $\mathrm{C}-\mathrm{O}-\mathrm{C}$ и $\mathrm{C}-\mathrm{O}_{2}$ в соответствии с данными работы [6]. Можно предположить, что образование связей отражает окисление графита по разорванным связям $\mathrm{C}-\mathrm{C}$. Наличие разорванных связей, а также групп $\mathrm{C}-\mathrm{O}$

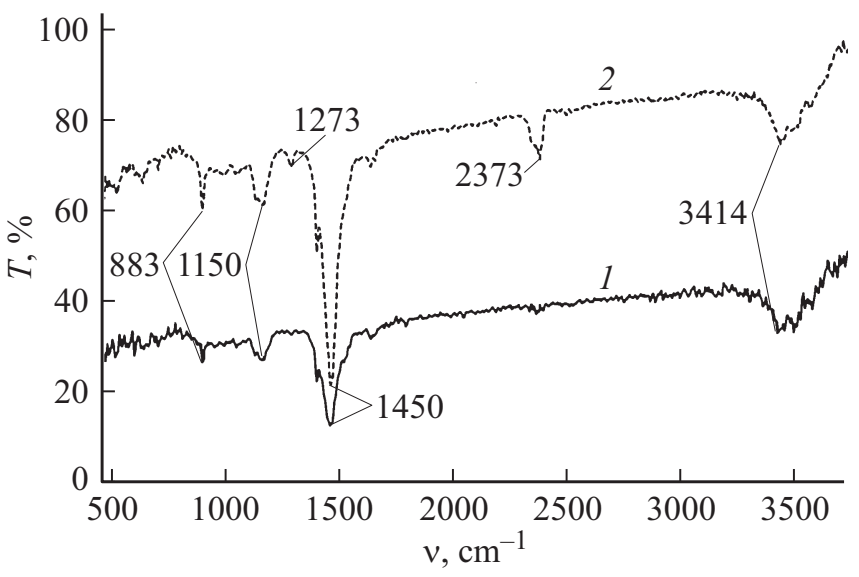

Рис. 3. Инфракрасные спектры порошка микронных частиц исходного графита (сплошная линия 1 ) и полученного из него графена (штриховая линия 2).

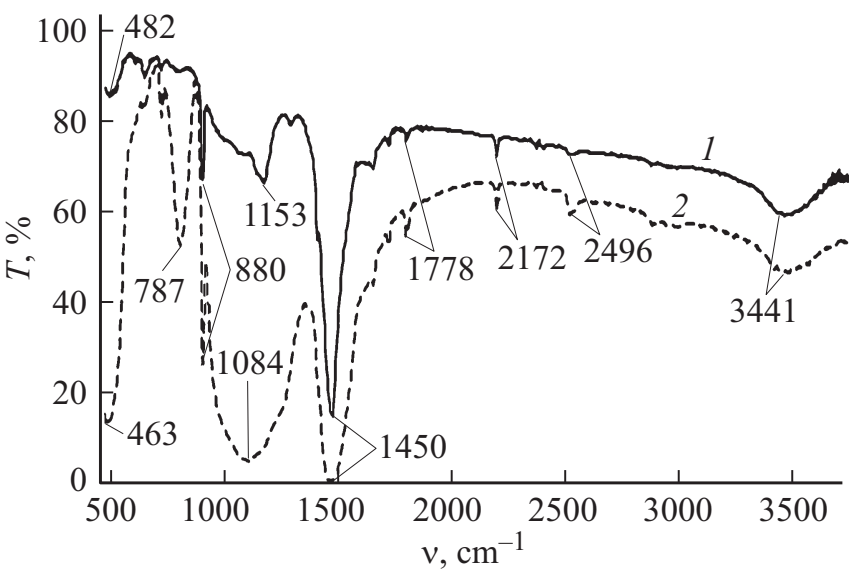

Рис. 4. Инфракрасные спектры графена в жидком стекле (сплошная линия 1) и жидкого стекла без графена (штриховая линия 2). 
на поверхности повышает реакционную способность полученного графена.

Поглощение в области $3414 \mathrm{~cm}^{-1}$ подтверждает присутствие $-\mathrm{OH}$ групп, вероятно, химически связанных на поверхности.

Графен, не имеющий ОН-групп на поверхности, гидрофобен, что затрудняет его введение в связующие. В ряде работ для диспергирования углеродных нанокластеров - фуллерена, нанотрубок - использовались органические сурфактанты, в частности карбоксиметилцеллюлоза, однако ее введение может быть нежелательным.

Было исследовано диспергирование графена в жидком стекле, которое представляет собой водный раствор силикатов натрия, имеющий щелочную реакцию и способный обеспечить связь с поверхностью. Кроме того, натриевое жидкое стекло в водном растворе имеет высокую вязкость, что также способствует стабилизации графена. Химический состав натриевого растворимого стекла может быть выражен формулой:

$$
\mathrm{Na}_{2} \mathrm{O} \cdot n \mathrm{SiO}_{2}+m \mathrm{H}_{2} \mathrm{O} \text {. }
$$

При высыхании или воздействии химических веществ из жидкого стекла выпадают коллоидные частицы двуокиси кремния.

Спектр графена в жидком стекле приведен на рис. 4. Прокаливание перед измерениями спектров проводилось при $200^{\circ} \mathrm{C}$.

Сравнение двух спектров показывает, что максимум при $787 \mathrm{~cm}^{-1}$, который присутствует в спектре жидкого стекла, при смешивании его с графеном исчезает. По данным книги [7] этот максимум может быть отнесен к колебанию боковой группы водорода. Вероятно, она существует в жидком стекле и образует связь с поверхностью графена при его диспергировании.

\section{Заключение}

Выполненное исследование показывает метод получения одной из разновидностей многослойного графена на основе ультразвукового отшелушивания плоскостей от частицы графитового порошка. Проведено исследование химической структуры поверхности полученных частиц. Предложен метод стабилизации частиц неорганическим сурфактантом - натриевым жидким стеклом и исследованы образующиеся при этом химические связи с поверхностью графена. Результаты могут быть интересны для применения многослойного графена в полимерных и стеклообразных композициях.

\section{Список литературы}

[1] Verma S., Dutta R.K. // RSC Advances. 2015. V. 5. N 94. P. 77192-77203.

[2] Hirata M., Gotou T., Horiuchi S., Fujiwara M., Ohba M. // Carbon. 2004. V. 42. P. 2929-2937.
[3] Woltornist S.J., Alhashmi Alamer F., McDannald A., Jain M., Sotzing G.A., Adamson D.H. // Carbon. 2015. V. 81. P. 38-42.

[4] Arnold T., Chu Chuan Dong, Thomas R.K., Castro M.A., Perdigon A., Clarke S.M., Inaba A. // Phys. Chem. Chem. Phys. 2002. V. 4. P. 3430-3435.

[5] Гончаров В.В., Бурдаков Н.С., Виргильев Ю.С., Карпухин В.И., Платонов П.А. Действие облучения на графит ядерных реакторов. М.: Атомиздат, 1978. 272 с.

[6] Si Y., Samulski E.T. // Nano Letters. 2008. V. 8. N 6. P. 1679-1682.

[7] Colthup N.B., Daly L.H., Wiberley S.E. Introduction to Infrared and Raman Spectroscopy, 3rd ed. London: Academic Press, 1990. 547 p. 